\title{
Federal
}

Governance

\section{INTRODUCTION \\ FEDERALISM, LOCAL GOVERNMENT AND POLICY-MAKING}

by Anna Gamper* and Francesco Palermo**

* Faculty of Law, University of Innsbruck, Austria

Email: Anna.Gamper@uibk.ac.at

** Institute for Studies on Federalism and Regionalism, EURAC Bolzano/Bozen, Italy Email: Francesco.Palermo@eurac.edu

Keywords: federalism, local government, policy-making 


\begin{abstract}
About Federal Governance
Federal Governance is an online graduate journal on theory and politics of federalism and multilevel governance. Its mandate is to engage the global federalism community and reach out to outstanding graduate students interested in federalism and multi-level governance. By providing a platform for graduate students to have early success in their careers, Federal Governance seeks to promote and sustain interest in federalism and multi-level governance research among graduate students. Allied with the Forum of Federations and founding partner, Institute of Intergovernmental Relations at Queen's University; Federal Governance aims to contribute to a global dialogue on federalism.
\end{abstract}

Co Chairs, Advisory Committee:

Rupak Chattopadhyay and Christian Leuprecht

Publisher:

Forum of Federations

Managing Editor:

Annegret Eppler

Associate Editors:

Joshua Cerovski, Dominic Heinz,

Eva-Maria Maggi and Victoria Tait

\title{
Terms of Use
}

Your use of this Federal Governance article indicates your acceptance of Federal Governance's Terms and Conditions of Use, available at www.federalgovernance.ca/terms. Federal Governance's Terms and Conditions of Use provides that you may use Federal Governance content only for personal, academic and non-commercial use. Each copy of any part of this Federal Governance article must contain the same copyright notice that appears on the screen or printed page of such transmission. 


\section{Introduction}

Local government is one of the less explored and yet most relevant aspects of federal studies. This has to do with the deep transformations federalism is undergoing in present times. The classical, centripetal model of federalism in fact is based on a dual system of government: the federal government and the constituent ones. As a consequence, local government was seen not as a genuine part of the picture, but rather as a subject-matter falling within the exclusive jurisdiction of the constituent units of a federation. It is not by chance that the oldest federal constitution of the world, the US constitution, does not mention local government at all.

Due to several reasons this view has significantly changed over time, among them the hybridation of the classical idea of two-tiered federalism and above all the practical relevance of the local government in a multilayered and multiplayer system of government. The constitutional recognition of local government as an autonomous order of government - which is often directly linked to the federal level and responsible for an increasing number of policy fields as well as financial management - is a more recent phenomenon in federal states (see N. Steytler, 2009).

Consequently, the growing role of local government has a considerable impact on federal systems. Local entities of all kinds, including inter-municipal associations, play an important role in the governance of each country. They are usually vested with competences that have to do with the citizens' everyday life such as public services, building and zoning of towns, villages and rural areas, social welfare, culture, leisure, local economic development, schooling, and alike. Furthermore, local government is the area of government which is naturally more open to the application of new instruments of governance because it is the level closest to the citizens and grants direct participation to a higher degree.

Local government takes many different functions and forms. Thus, it can be observed and analyzed from a wide range of different angles. This is what the papers presented in this special issue do. The striking diversity of the topics dealt with by the four papers exemplifies the broad scope of local government studies as an essential component of modern research on federalism. They also represent different disciplinary approaches, reaching from economics to political science. Aisling Lyon focuses on an outstanding example of how local government reform could ease inter-ethnic tensions in the former Yugoslav Republic of Macedonia, becoming the key for preserving the multi-ethnicity of that State. Taweesak Kritjaroen illustrates the case study of the solid-waste management in a Thai municipality as an example of how public-private partnerships deliver complex public services. Mariia Sydorovych presents the system of financing local government in Ukraine from an economic and legal perspective and Sisira Saddhamangala Withanachchi analyses the impact of local government and some of its participatory instruments on the economic development of underdeveloped areas by presenting the case of two Sri Lankan municipalities.

Although none of the papers directly deals with traditional areas of federal studies or with federal countries, their publication in "Federal Goverance" is due to several reasons. First, this special issue intends to focus on local government and its potential, stimulating further reflection on this topic especially by readers well trained in federal studies, such as the target group of "Federal Governance". Second, the papers aim at 
presenting the broadness of the potential spectrum of local government issues including areas that are more traditionally dealt with by classical federal studies such as inter-ethnic accommodation, financial intergovernmental relations and individual policy fields. Third, they present cases from very different parts of the world, which is what international scholars on federalism are interested in. Lastly, and perhaps most importantly, the papers do not result from a call; rather, they were presented and discussed in February 2010 within the framework of the International Winter School on Federalism and Governance, a common initiative by the Institute for Studies on Federalism and Regionalism of the European Academy Bolzano/Bozen (Italy) and by the University of Innsbruck (Austria), with both its Faculty of Law and its School for Political Science and Sociology.

Under the patronage of the Secretary General of the Council of Europe, young scholars and practitioners on federalism from all parts of the world meet in Innsbruck and Bolzano for two weeks - at the crossroad between the established federal system of Austria and Italian federalism in the making. The International Winter School on Federalism and Governance analyses in depth the phenomena of federalism, regionalism and multi-level governance from a comparative legal and a political science perspective. Every Winter School edition pays special attention to a particular topic, which is approached in detail by outstanding legal scholars, political scientists and practitioners. The 2010 Winter School, where these papers were presented, focussed on local government. In the following years other major topics of federalism, such as cross-border cooperation (2011) and the protection of minorities (2012), were and will be studied in the context of federalism. Readers of "Federal Goverance" are cordially invited to apply for participation in coming years.

It is our hope that the papers presented in this issue of "Federal Governance" will stimulate further reflection on both the theoretical and practical importance of local government for every federal system.

\section{References}

[1] Steytler N. 2009, Comparative conclusions, in N. Steytler (ed.), Local Government and Metropolitan Regions in Federal Systems, A global dialogue on Federalism, Vol. 6, Montreal \& Kingston, pp. 393-436 